\title{
土壤面蒸発を土壤水分傾度より推定する方法 (続報)
}

\author{
丸山栄三・高砂学 \\ (気象庁産業気象課) \\ Determination of Evaporation from a Soil Surface \\ by Measuring the Gradient of Soil Moisture \\ E. MARUYAMA and M. TAKASUNA \\ (Industrial Moteorology Section, Japan Meteorological Agency)
}

\section{1. 土壤からの蒸発を表わす式}

土壤中に抢ける水分移動の形は主として, 液相と蒸気 相の二種類にわけることができる。もつともこれ以外に 空気中の水分を吸収する, 吸湿による表層の水分变化も 起るが，これは蒸発過程の問題としては無視できるよう である。液相による移動も重力水を考虑に入れる必要の ある過飽和土壌の場合を除けば，面から面へ毛管力によ る移動を考学ることによつて充分表現できる。この蒸発 を表わす式については，序報1でそれが熱流に近似でき ることと，その測定結果について報告した。つまりそれ は土壤の乾燥過程に括ける水分移動を熱伝導の式で表現 乙, 水分拡散係数を三層の土中水分量の变化から近似的 に求めて，それに水分量の傾度を乗ずることによつて土 畩面の蒸発を導びいたのである。

すなわち

$$
D=\frac{\partial \theta \mid \partial t}{\partial^{2} \theta \mid \partial x^{2}} \simeq \frac{\Delta \theta \mid \Delta t}{\Delta^{2} \theta \mid \Delta x^{2}} .
$$

$D$ は水分拡散俰数, $\theta$ は単位容積中の土壤水分量, $t$ は時間, $x$ は深さ, 蒸発量 $E$ は

$$
E=D \times \frac{\partial \theta}{\partial x}
$$

(1)，（2）両式から蒸発量を求めた。

\section{2. 土壤面蒸発の推定と二, 三の比較観測}

昭和 32 年 11 月 24 日より 28 日まで, この方法に よつて茨城県館野高層気象台の構内に括いて, 土埣面蒸 発量の観測を叔こなつた。をた測定值と比軟するために 直径 $25 \mathrm{~cm}$, 深さ $20 \mathrm{~cm}$ の鉄製円筒を自然状態を乱さ ぬ上5に土袞中に埋め(第 1 図)，それを毎時の 30 分に 大型天科（科量 $20 \mathrm{~kg}$. 感量 $0.5 \mathrm{~g}$ ) を使つてその減量 を測定し, 単位面積当りの蒸発量を $\mathrm{mm}$. で算出した。 これをここでは土壤直接科量による方法と呼ぶ。

このほか，同時に和こなわれた接地気象の観測資料か ら計算した土䁃面蒸発の値を借用しての比較をも試み た。この比較に使つた式は（3）式および（4）式であ る。

Thornthwaite-Holtzman の式

*，1958 年6月 20 日 関東支部例会に拈いて発表

$$
E=\frac{\rho K_{0}^{2}\left(u_{2}-u_{1}\right)\left(q_{1}-q_{2}\right)}{\left\{\ln \frac{z_{2}}{z_{1}}\right\}^{2}}
$$

ここで $u_{1}, u_{2}$ および $q_{1}, q_{2}$, は高さ $z_{1}, z_{2}$ に特ける 風速掠よび混合比， $\rho$ は空気の密度， $K_{0}$ はカルマン常 数, 単位は全て $\mathrm{C} \cdot \mathrm{G} \cdot \mathrm{S}$

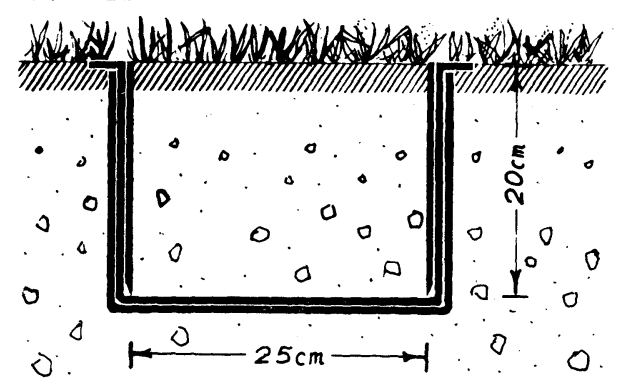

Fig. 1. Steel Cylinder Vessel

$$
E=-K_{v} \frac{\partial q}{\partial z}
$$

(4) 式は地面近くの水分の密度傾度に, 水蒸気の分子 抬散係数 (実際は地面温度と全ガス圧の函数であるがこ こでは 0.24 を採用）を乗じて蒸発量を算出した。

これらの観測を物こなつた附近の地形はかなり広大な 草地で, その表面を均一にするために雑草を焼払い，さ らにその一部分の表土の上部拉よび全部を削り取つた状 態,すなわち堹土扣よび心土を平らに露出させたもので ある。

観測は 24 日，25 日打よび 28 日の 3 日間括こなつ たが, 初めの 2 日は壤土について, 最後の 1 日だけは心 土について測定した。このほか, 土壌の表面に霜柱とし て析出した水分も, 単位面積当りについてとの量を秤量 し，析出水量として $\mathrm{mm}$ で見積つた。

以上の方法で求めた蒝発量の計算過程拈よびその值 と, 霜柱による析出水量を第 1 表に示した。な招第 1 表 で $\theta_{1}, \theta_{2}$ 抢よび $\theta_{3}$ は夫々土壤の表面より深さ $1 \mathrm{~cm}$ ま で, $1 \mathrm{~cm}$ より $2 \mathrm{~cm}$ まで, $2 \mathrm{~cm}$ より $3 \mathrm{~cm}$ までの土壤 を前報告と同じ採土円筒を使つて採土した。しかし土壤 不均一に上り, 一定容積の採土因難のため, 土壤の仮比 重 $\rho$ は平均値の採用を余儀なくされた。 
第 1 表 水分傾度より蒸発量の推定結果及び科量による蒸発量

\begin{tabular}{|c|c|c|c|c|c|c|c|c|c|c|c|c|c|}
\hline \multirow[b]{2}{*}{ 時 } & \multicolumn{3}{|c|}{$\begin{array}{l}\text { 土壤水 分 } \\
\text { Moisture con- } \\
\text { tent on wet } \\
\text { soil. \% }\end{array}$} & \multicolumn{3}{|c|}{$\begin{array}{l}\text { 水 分 } \frac{\text { 量 }}{\text { Moisture content }} \\
\text { on unite volume. }\end{array}$} & \multirow{2}{*}{ 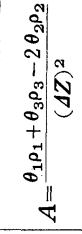 } & \multirow{2}{*}{ 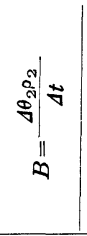 } & \multirow{2}{*}{$\mid \begin{array}{c}\infty \\
\| \\
0\end{array}$} & \multirow[t]{2}{*}{$\stackrel{N}{\nabla}$} & \multirow{2}{*}{ 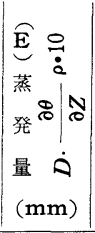 } & \multirow{2}{*}{ 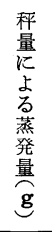 } & \multirow{2}{*}{ 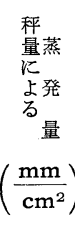 } \\
\hline & $\theta_{1}$ & $\theta_{2}$ & $\theta_{3}$ & $\theta_{1} \rho_{1}$ & $\theta_{2} \rho_{2}$ & $\theta_{3} \rho_{3}$ & & & & & & & \\
\hline 5 & 58.9 & 41.3 & 57.1 & 0.530 & 0.372 & 0.514 & & & & & $(0.31)$ & & \\
\hline 6 & 40.5 & 42.5 & 44.0 & 0.365 & 0.382 & 0.396 & & & & & $(1.50)$ & & \\
\hline 7 & 41.9 & 42.1 & 42.6 & 0.377 & 0.379 & 0.373 & -0.008 & & & & $(0.50)$ & & \\
\hline 8 & 43.3 & 43.7 & 43.0 & 0.390 & 0.393 & 0.387 & -0.009 & & & & $(0.00)$ & & $\ldots$ \\
\hline 9 & 43.1 & 44.0 & 44.6 & 0.388 & 0.396 & 0.401 & -0.003 & 0.0015 & 0.50 & 0.0065 & 0.0325 & & $\ldots$ \\
\hline 10 & 41.9 & 43.6 & 43.9 & 0.377 & 0.392 & 0.395 & -0.012 & 0.0075 & 0.62 & 0.0090 & 0.0450 & & $\ldots$ \\
\hline 11 & 40.8 & 42.0 & 42.7 & 0.367 & 0.380 & 0.384 & -0.009 & 0.0100 & 1.11 & 0.0085 & 0.0944 & & $\ldots$ \\
\hline 12 & 38.1 & 40.5 & 42.0 & 0.343 & 0.365 & 0.378 & -0.009 & 0.0100 & 1.11 & 0.0175 & 0.1943 & 8.0 & 0.17 \\
\hline 13 & 36.5 & 39.2 & 41.4 & 0.330 & 0.357 & 0.373 & -0.011 & 0.0070 & 0.63 & 0.0215 & 0.1355 & 8.0 & 0.17 \\
\hline 14 & 41.8 & 43.9 & 44.7 & 0.378 & 0.395 & 0.402 & -0.010 & 0.0080 & 0.80 & 0.0120 & 0.0860 & 6.5 & 0.12 \\
\hline 15 & 41.0 & 43.0 & 43.5 & 0.369 & 0.387 & 0.392 & -0.013 & 0.0095 & 0.73 & 0.0115 & 0.0890 & 4.0 & 0.09 \\
\hline 16 & 39.5 & 41.8 & 42.6 & 0.359 & 0.376 & 0.383 & -0.010 & 0.0090 & 0.90 & 0.0120 & 0.1080 & 2.0 & 0.04 \\
\hline 17 & 38.7 & 40.7 & 41.7 & 0.348 & 0.366 & 0.375 & -0.009 & 0.0060 & 0.67 & 0.0135 & 0.9805 & 1.5 & 0.04 \\
\hline 18 & 40.7 & 41.1 & 41.6 & 0.366 & 0.370 & 0.374 & -0.000 & & & & $(0.10)$ & 0.5 & 0.01 \\
\hline 19 & 42.4 & 48.8 & 45.7 & 0.382 & 0.439 & 0.413 & +0.083 & & & & $(0.12)$ & & \\
\hline
\end{tabular}

$\rho_{1}, \rho_{2}, \rho_{3}$ は夫々平均値 0.9 を採用 （）は霜柱量 $\mathrm{mm} / \mathrm{cm}^{2}$

\begin{tabular}{|c|c|c|c|c|c|c|c|c|c|c|c|c|c|}
\hline $6_{15}$ & 48.18 & 47.43 & 46.97 & 0.4963 & 0.4885 & 0.4838 & \multirow{5}{*}{$(-0.0083)$} & \multirow[b]{5}{*}{-0.011} & \multirow[b]{5}{*}{ (1.32) } & \multirow[b]{5}{*}{0.00805} & $(1.00)$ & 0.0 & $\cdots$ \\
\hline 7 & 48.76 & 48.15 & & 0.5022 & 0.4959 & & & & & & $(0.90)$ & 0.0 & $\cdots$ \\
\hline 8 & 46.45 & 49.57 & 50.16 & 0.4784 & 0.5106 & 0.5166 & & & & & $(0.07)$ & 0.0 & $\cdots$ \\
\hline 9 & 50.20 & 49. 63 & 49.60 & 0.5171 & 0.5112 & 0.5109 & & & & & - & 4.0 & 0.08 \\
\hline 10 & 47.55 & 48.74 & 49.12 & 0.4898 & 0.5020 & 0.5059 & & & & & 0.106 & 7.0 & 0.14 \\
\hline 11 & 46.00 & 47.60 & 48.80 & 0.4738 & 0.4903 & 0.5026 & -0.0042 & -0.013 & 2.62 & 0.01420 & 0.372 & 8.0 & 0.16 \\
\hline 12 & 45.62 & 46. 18 & 46.41 & 0.4699 & 0.4757 & 0.4780 & -0.0035 & -0.014 & 4.00 & 0.0041 & 0.164 & 5.5 & 0.11 \\
\hline 13 & 39.69 & 42.20 & 42.74 & 0.4088 & 0.4347 & 0.4402 & -0.0204 & -0.041 & 2.00 & 0.01570 & 0.314 & 6.5 & 0.13 \\
\hline 14 & 38.56 & 40.80 & 41.50 & 0.3972 & 0.4162 & 0.4275 & -0.0177 & -0.0303 & 1.70 & 0.00930 & 0.158 & 5.5 & 0.07 \\
\hline 15 & 39.00 & 40.21 & 40.81 & 0.4017 & 0.4142 & 0.4203 & -0.0064 & -0.0160 & 2.50 & 0.00930 & 0.233 & 3.5 & 0.07 \\
\hline 16 & 41.46 & 43.17 & 45.24 & 0.4270 & 0.4447 & 0.4660 & & & & & & 1.5 & 0.03 \\
\hline 17 & 43.76 & 46.24 & 46.11 & 0.4507 & 0.4163 & 0.4749 & & & & & & 0.5 & 0.01 \\
\hline 18 & 43.47 & $\cdots$ & 45.17 & 0.4477 & $\cdots$ & 0.4653 & & & & & Dew & 1.5 & 0.03 \\
\hline 19 & 40.49 & 41.26 & $\cdots$ & 0.4963 & 0.4885 & 0.4838 & & & & & Dew & 0.5 & 0.01 \\
\hline & & & & $\rho_{1}, \rho_{2}$, & 年 & 至均俌 & 1.03 & - & 量 $\mathrm{mn}$ & $1 / \mathrm{cm}^{2}$ & & & \\
\hline 7 & 50.03 & 48.30 & 49.15 & 0.6104 & 0.6327 & 0.6439 & & & & & & 0.5 & 0.012 \\
\hline 8 & 49.18 & 49. 24 & 48.95 & 0.6000 & 0.6450 & 0.6412 & & & & & & 0.0 & 0.000 \\
\hline 9 & 48.60 & 48.72 & 49. 37 & 0.5929 & 0.6382 & 0.6400 & -0.0435 & -0.0053 & 0.12 & 0.0236 & 0.0283 & 3.0 & 0.060 \\
\hline 10 & 48. 30 & 48.51 & 48.81 & 0.5893 & 0.6355 & 0.6394 & -0.0423 & -0.0026 & 0.07 & 0.0251 & 0.0176 & 8.0 & 0.163 \\
\hline 11 & 48.05 & 48.45 & 49.10 & 0.5862 & 0.6325 & 0.6432 & -0.0356 & -0.0030 & 0.14 & 0.0285 & 0.0400 & 10.5 & 0.215 \\
\hline 12 & 47.86 & 48.10 & 48.19 & 0.5839 & 0.6301 & 0.6313 & -0.0450 & -0.0080 & 0.18 & 0.0287 & 0.0508 & 9.5 & 0.190 \\
\hline 13 & 47.54 & 47.76 & 47.77 & 0.5800 & 0.6257 & 0.6258 & -0.0456 & -0.0030 & 0.07 & 0.0229 & 0.0160 & 10.8 & 0.220 \\
\hline 14 & 48.07 & 48.21 & 48.33 & 0.5865 & 0.6316 & 0.6331 & -0.0436 & -0.0020 & 0.05 & 0.0233 & 0.0117 & 3.0 & 0.060 \\
\hline 15 & 47.50 & 47.91 & 47.25 & 0.5795 & 0.6276 & 0.6190 & -0.1020 & -0.0044 & 0.04 & 0.0198 & 0.0080 & 4.5 & 0.090 \\
\hline 16 & 48.63 & 48.02 & 47.77 & 0.5933 & 0.6291 & 0.6258 & & & & & & & \\
\hline 17 & 48.64 & 48.21 & 48.21 & 0.5934 & 0.6316 & 0.6316 & & & & & & & \\
\hline
\end{tabular}
$\rho_{1}, \rho_{2}, \rho_{3}$ は夫々平均値 $1.22,1.31,131$

また第 1 表の蒸発量と（3）式拈よび（4）式の方法より求 めた蒸発量の比較, および霜柱の日変化を第 2 図に示した。

これを 24 日の結果についてみると，筆者等の方法に よつて推定した蒸発量の変化は, 土壤直接科量による值 および（4）式よりの推定値とよく似ているが，（3） 式の值はこれらよりかなり小さい值となつている。

次に 25 日の場合は比較的雲量の変化が多かつたため 蒸発量も変動が大きい。しかし傾向としては（4）式の 值にかなり近く，土壤直接科量による值はこれらよりも 小さくでている。また（3）式は24 日の場合と同じく 全般的に小さい。ところが 28 日になるとこれらと逆で

卓越した。
(3) 式と科量による 値は大きく，(4)式と 土壤水分傾度よりの推 定值が小さいが，両者 はかなり類似している。

総括的に言えば筆者 等の測定值と (4) 式 による值とはよく合致 するが，土壤直接科量 による值や（3）式に よる値とはかなりの差 異がある。このように 我々の測定值が（4) 式の値とよく一致する ことは, 我々の測定方 法や（4）式による方 法は, いづれも原理的 に見ると小地域の土壌 面蒸発量を推定するの に好都合な方法である からであろ5。これに 対して (3) 式は元来 自由水面に適応される べき式であり，少くと もかなり広大な地域の 蒸発散量をよく表現す るものとして使用され ている。したがつて不 均一な小地域に使用す る場合は, 周囲よりの 移流などが起り得るか ら, 筆者等の計算値に 合致しないのは当然か もしれない。事実この 場合も 24 日，25日は 北寄りの風が吹いたが 28 日には南風が時々
また土壤直接科量に使用する円壔内 6 ケ所の土㙥水分 と, 外部 3 ケ所の土壤水分を測定した結果は第 2 表のよ ラになつている。

第 2 表によると, 円壔内部は全般的に外部より乾燥し ている。これは土壌が有底な円壔につめられているた め，外部との毛管が断ち切れて下方よりの水分補給がな い結果と思われる。

霜柱として析出した水量も第 2 図に示したがその量は 
註 $\mathrm{A}$ : 土壌水分傾度より

(by soil moisture gradient))

B : 土壤直接科量より

(by steel cylinder)

C : Thornthwaite-Holtzman $の$ 式より

$\mathrm{D}:(4)$ 式より

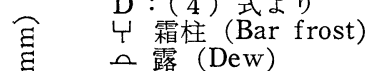

ह $几$ 露 (Dew)
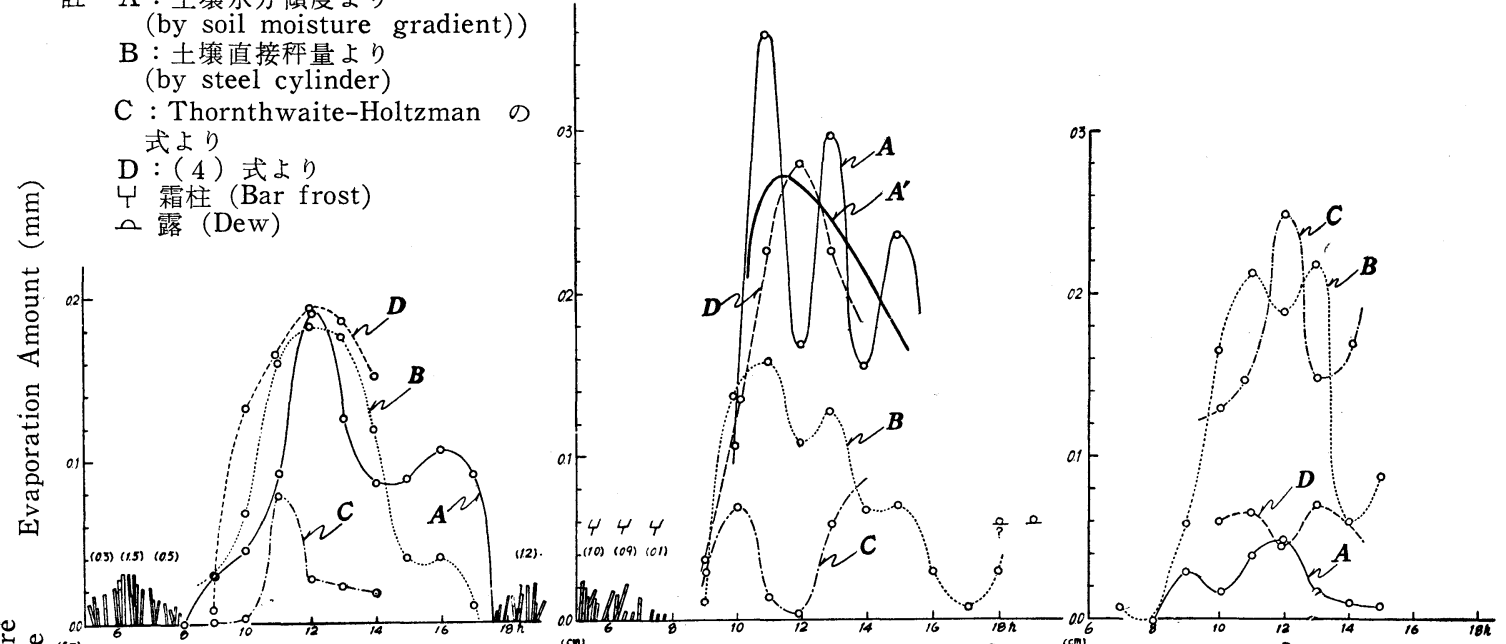

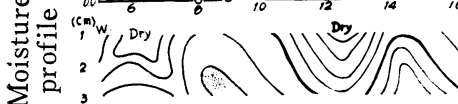
Wet

Nov. 24 th Loam

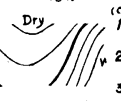

$\left.\int / \int_{n^{2}}^{(c m)}{ }_{3}^{(m)}\right)^{D x y} \int_{A}^{D y}$

Wet

Nov. 25 th Loam

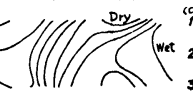

(wet ${ }_{2}$

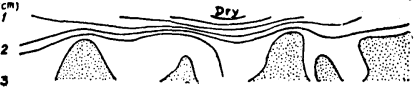

Wet Wet Wet wet

Nov. 28 th clay

Fig. 2. Comparison of Evaporation from a soil surface estimated from various methods

第 2 表 鉄製円壔内外の土壌水分 (11 月 26 日 15 時)

\begin{tabular}{cc|c|c|c|c}
\hline & & \multicolumn{4}{|c}{ 土裹 水 分 $\%$} \\
\cline { 3 - 6 } 測 定 部 位 & 1 & 2 & 3 & 平均 \\
\hline 外 & 部 & 41.4 & 41.0 & 43.3 & 41.9 \\
円 壔 の 中 心 & 35.0 & 36.4 & 38.3 & 36.6 \\
円壔外周より内部へ $1 \mathrm{~cm}$ & 32.0 & 33.5 & 33.0 & 32.8 \\
\hline
\end{tabular}

意外に多く, 特に 24 日の観測によれば最高 $15 \mathrm{~mm}$ の 水量に相当する。な特この時の土壤中の水分のプロフィ 一ルを見ると，蒸発が盛んな日中の場合と同じ分布をし て拉り，これが日出後融けて再び土壤中に侵入するため 内部の水分が急激に增大している。

これから見ても霜柱が土中の水分輸送に果している役 割はゆるがせにできないものである。

\section{3. 後 記}

Philip 执よび De Vries は, 土壤中の水分移動を詳 細に記述する一般式として, 液相括よび蒸気相の移動が 温度場や水分場の影響を考慮に入れる必要があるとして 次式を提出している。

$$
\partial \theta / \partial t=\nabla\left(D_{T} \nabla T\right)+\nabla \cdot\left(D_{\theta} \nabla \theta\right)+\partial K / \partial Z \cdots(5)
$$

上式で $\theta$ は土壤の単位容積中の水分量, $D_{\theta}$ は土壌の 水分拡散係数で，これと水分との関係は第 3 図の左のと 扣りに変化する。また $D_{T}$ は温度拡散係数でこれも水分 によつて変化するが（第 3 図中央）水分の比較的大きい 範囲ではあまり変化しない。さらにまた $K$ は水分伝導

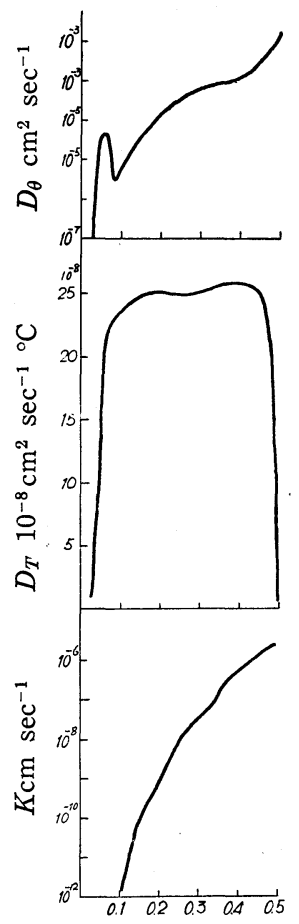

Fig, 3. $D_{\theta} \quad D_{T}$ and $K$ : all as function of moisture content for Yolo light clay at $20^{\circ} \mathrm{C}$ (after philip and De Vries.)

Moisture content on - unit volume

度 (Hydraulic Conductivity) でこれも第 3 図右のよう に水分とともに変化している。

上式でもし土壌の薄層や内部の問題を取扱う限り, 土 
壤中の温度場の影響が無視できる場合には（5）式は

$$
\frac{\partial \theta}{\partial t}=\nabla\left(D_{\theta} \nabla \theta\right)+\partial K / \partial Z
$$

となる。

また第 3 図 (中央) のと括り $K$ む $\theta$ の函数である が，薄層を取扱い，土層に水分傾度がさほど大きくない 場合には， $\partial K / \partial Z$ は殆ど無視することができる。した がつて第 6 式は $\partial \theta / \partial t=\nabla\left(D_{\theta} \cdot \nabla \theta\right) \cdots \cdots \cdots(7)$ とな り, 近似計算としての水分移動を記述する一般式は, 熱 流を表わす筆者等の式と全く同じものになる。ただし $D_{\theta}$ の值が第 3 図左に示したと括り， $\theta$ と共にかなり変 化する場合には ( 7 ) 式の簡単な解は求められず, 筆者 等の方法から蒸発量を求めることは不可能になる。

\section{参考文 献}

1）鈴木清太郎・丸山栄三
土壤面蒸発を土壤水分の傾度より推定する方法 （序報） 農業気象 13 巻 2 号

2) J.R. Philip \& D. A. De Vries :

Moisture Movement in Porous Material under Temperature Gradient.

Transaction American Geophy. Union. 1957. $38,2$.

3) J.R. Philip :

Evaporation, Moisture and Heat Field in the Soil. J. Met. 1955.

4) H.L. Penman :

Laboratory Experiments on Evaporation from Fallow Soil.

J. Agr. Soc. 1931.

5) J.R. Philip :

An Infiltration Equation with Phisical Significance. Soil Sci. 77, 1954. a.

\section{Summary}

The report on the possibility of computing the amount of evaporation from the soil surface using the vertical moisture gradient measured in the soil was made in the previous experimental study (Suzuki, S and Maruyama, E. 1957).

We measvred the evaporation from the surface of loam-and clay-soil by the method mentioned in the previous report, in the vast plain field attached to the Aero-Meteorological Observatory, Tateno in Ibaragi Prefecture, and at the same time in order to check the actual amount of evaporation from the same soil, we weighted hourly a steel cylinder vessel containing loam and clay-soil in it imbeded in the earth of the same soil structure.

Those two methods led to the vary same values. At the same time the values were found coincided with the ones estimated from the vertical gradient of vapour density in the atmosphere near the ground which was observed by another member of our observation group in the neighbourhood of the Observatory.

It was of much interest that the values calculated by means of Thornthwaite-Holtzman's formula reffered to the vertical distributions of wind-velocity, relative humidity and temperature, which were observed by the same group and in the same place, were found considerably different from ours.

\section{本 会 記 事}

\section{北海道支部第 8 回総会並びに第 12 回例会 報告}

昭和 34 年 11 月 21 日午前 10 時より北大農学部におい て開催され，下記の如き研究発表がなされた。参会者は 35 名であつた。な総会に拈いて役員の改選が行われ た（結果省略）

1. 温水池の熱効率の定義について （北農試）千葉 豪

2. 農場内に打ける気象条件の差異について （北大農）横田廉一, 前田隆, 石橋 憞, 秋田谷英次

3. 冷水灌穊地帯に打ける水田の温度

（支 部 長）八 鍬 利 助

(山形大農）羽根田栄四郎
4. イロリに関する調査研究

（北大農）横田廉一，（鳥取大農）尾崎 繁 （佐用農高）篠原弘已

5. 南空知に扣ける水稲水害の被害様相について （札統調指導官室）山田 正

6. 沙流川の水温について（II）

（北大農）前田 隆,（道土地改良課）池田 実

7. W. M. O. CAg M の共同研究報告

第 1 報 地温の観測について (序報)

（支 部 長）八鍬利助

（札幌気象台）石井幸夫, 菅原 和

8. 波状試験に打ける風蝕の実態について （北海道開発局）湯川邦三 （北農試）藤原 忠, 大根田襄 楠瀬昌彦 